\title{
Stereotactic Body Radiotherapy: Do Central Lung Tumors Still Represent a 'No-Fly Zone'?
}

\author{
Suresh Senan \\ Department of Radiation Oncology, VU University Medical Center, Amsterdam, The Netherlands
}

Few recent developments in the treatment of NSCLC have matched the impact that stereotactic body radiotherapy (SBRT) has had on outcomes in early-stage NSCLC. Also referred to as stereotactic ablative radiotherapy, SBRT is high-precision radiotherapy that is typically delivered using 1-8 fractions, and which is characterized by daily doses ranging from 7.5 to 18 Gy [1]. Prospective multicenter studies report local control rates exceeding $90 \%$ after SBRT for peripheral lung tumors measuring up to $5 \mathrm{~cm}[2,3]$. Data from the Dutch National Cancer Registry revealed that the nationwide introduction of SBRT was associated with improvements in median survival of elderly patients in the Dutch population, from 16.8 to 26.1 months [4]. However, early reports on outcomes of SBRT for tumors in the perihilar and/or central regions observed increased bronchial and esophageal toxicity when daily dose fractions ranging from 10 to 22 Gy were used $[5,6]$. These reports led to the widely cited concept of a central 'no-fly zone' for SBRT in North America.

Recent reports from European groups who delivered SBRT to central tumors using so-called 'risk-adapted' fractionation schemes, in which daily dose fractions of $7.5 \mathrm{~Gy}$ or lower were used, suggest that high local control rates can be achieved with minimal toxicity [7, 8]. A paper in this issue by Janssen et al. on 65 patients treated using SBRT at a single institution provides further insight into the use of SBRT for central tumors measuring up to $142 \mathrm{ml}$ [9]. Included were 26 patients with stage III NSCLC $(\mathrm{n}=16)$ or stage IV disease $(\mathrm{n}=10)$, with the latter comprising patients in whom treatment of the primary was judged to be necessary for symptom control and/or quality of life. SBRT delivery was performed with a meticulous approach using 4-dimensional planning CT scans, daily treatment setup on tumor position with conebeam CT scans, and perhaps most importantly, a risk-adapted SBRT scheme delivering 8 fractions of either 6 or 5 Gy. Treatment-related toxicity was acceptable, although the median follow-up of 13.8 months is relatively short. One drawback of the paper is a lack of detail provided on inclusion or exclusion criteria used for stage III tumors. Including patients with multiple ipsilateral mediastinal nodes, or those with any contralateral metastases, will inevitably increase doses to critical normal organs. Were high doses to the esophagus a reason to exclude patients, or to use a fraction size of $5 \mathrm{~Gy}$, or even to accept lower tumor doses, as has been reported recently [8]? Further progress in this field requires detailed dosimetric data on esophageal and tracheal doses, which in turn must be correlated with both acute and late toxicity. In addition, the use of a staging PET-CT scan in less than $50 \%$ of all their cases is of concern, as loco-regional recurrences developed in $11 \%$ of cases. Nevertheless, the current report is useful and adds to the growing data from ongoing studies of SBRT in central lung tumors.

Even if recurrence rates and late toxicity observed by the authors changes on longer follow-up, interest in using SBRT for central tumors will grow, particularly in the light of data from the surgical literature on much fitter patient cohorts. In a phase III study, 270 European patients with early stages IB, II, or IIIA NSCLC who were randomly assigned to receive either 3 cycles of induction chemotherapy followed by surgery, or surgery [10]. Despite having a median age of 61.8 years, and with $72 \%$ of patients having an ECOG performance status of 0 , perioperative mortality rates observed were 3 and $4 \%$, respectively. Furthermore, a complete resection was achieved in only 88 and $84 \%$ of patients, respectively, with subsequent disease progression at the site of primary tumor seen in 9.3 and $10.6 \%$. Finally, lymph node relapses occurred in $13.2 \%$ of patients in the chemotherapy plus surgery arm, and $6.4 \%$ of patients in the surgery alone arm. Such findings suggest that the recurrence rates and toxicity reported thus far with SBRT for central tumors in unfit patients can be considered acceptable.

The safety of combining sequential chemotherapy and SBRT remains to be investigated before this treatment approach can be routinely implemented in patients with stage III NSCLC who are unfit to undergo conventional concurrent

\section{KARGER}

Fax +497614520714

Information@Karger.de

www.karger.com (c) 2012 S. Karger GmbH, Freiburg

0378-584X/12/0357-0406\$38.00/0

Accessible online at:

www.karger.com/onk
Prof. Suresh Senan, M.D.

Department of Radiation Oncology,

VU University Medical Center,

De Boelelaan 1117, Postbox 7057, 1007 MB Amsterdam, The Netherlands

Tel: +31204440436

s.senan@vumc.nl 
chemo-radiation. In patients who refuse the latter, SBRT schemes could be compared to more conventional accelerated radiotherapy schemes. Until more reliable dosimetric data become available, central lung tumors may be more appropriately considered as a 'fly-with-caution' zone, rather than being an unequivocal 'no-fly zone' for SBRT.

\section{Disclosure Statement}

The Department of Radiation Oncology at the VU University Medical Center has received research funding from Varian Medical Systems. Suresh Senan has received speaker's honoraria from Varian Medical Systems.

\section{References}

1 Palma D, Senan S: Stereotactic radiation therapy: changing treatment paradigms for stage I nonsmall cell lung cancer. Curr Opin Oncol 2011;23: 133-139.

- 2 Timmerman R, Paulus R, Galvin J, Michalski J, Straube W, Bradley J, Fakiris A, Bezjak A, Videtic G, Johnstone D, Fowler J, Gore E, Choy H: Stereotactic body radiation therapy for inoperable early stage lung cancer. JAMA 2010; 303:1070-1076.

>3 Baumann P, Nyman J, Hoyer M, Wennberg B, Gagliardi G, Lax I, Drugge N, Ekberg L, Friesland S, Johansson KA, Lund JA, Morhed E, Nilsson K, Levin N, Paludan M, Sederholm C, Traberg A, Wittgren L, Lewensohn R: Outcome in a prospective phase II trial of medically inoperable stage I non-small-cell lung cancer patients treated with stereotactic body radiotherapy. J Clin Oncol 2009;27:3290-3296.
4 Haasbeek CJ, Palma D, Visser O, Lagerwaard FJ, Slotman BJ, Senan S: Early-stage lung cancer in elderly patients: a population-based study of changes in treatment patterns and survival in the Netherlands. Ann Oncol 2012 DOI: 10.1093/ annonc/mds081.

5 Timmerman R. McGarry R, Yiannoutsos C, Papiez L, Tudor K, DeLuca J, Ewing M, Abdulrahman R, DesRosiers C, Williams M, Fletcher J: Excessive toxicity when treating central tumors in a phase II study of stereotactic body radiation therapy for medically inoperable earlystage lung cancer. J Clin Oncol 2006;24:4833-4839.

6 Song SY, Choi W, Shin SS, Lee SW, Ahn SD, Kim JH, Je HU, Park CI, Lee JS, Choi EK: Fractionated stereotactic body radiation therapy for medically inoperable stage I lung cancer adjacent to central large bronchus. Lung Cancer 2009;66:8993.
7 Haasbeek CJA, Lagerwaard FJ, Slotman BJ, Senan S: Outcomes of stereotactic ablative radiotherapy for centrally located early-stage lung cancer. J Thorac Oncol 2011;6:2036-2043.

8 Nuyttens JJ, van der Voort van Zyp NC, Praag J, Aluwini S, van Klaveren RJ, Verhoef C, Pattynama PM, Hoogeman MS: Outcome of four-dimensional stereotactic radiotherapy for centrally located lung tumors. Radiother Oncol 2012; 102:383-387.

9 Janssen S, Dickgreber NJ, Koenig C, Bremer M, Werner M, Karstens JH, Welte T, Meyer A: Image-guided hypofractionated small volume radio-therapy of non-small cell lung cancer -feasibility and clinical outcome. Onkologie 2012;35: DOI: 10.1159/000340064.

10 Scagliotti GV, Pastorino U, Vansteenkiste JF, Spaggiari L, Facciolo F, Orlowski TM, Maiorino L, Hetzel M, Leschinger M, Visseren-Grul C, Torri V: Randomized phase III study of surgery alone or surgery plus preoperative cisplatin and gemcitabine in stages IB to IIIA non-small-cell lung cancer. J Clin Oncol 2012;30:172-178. 